\title{
Radiometric ages of quartz diorite bodies related to the Chichibu pyrometasomatic deposits and their relevance to the metallogenetic epoch
}

\author{
Hirotomo Ueno* and Ken Shibata** \\ *Institute of Mineralogy, Petrology and Economic Geology, \\ Faculty of Science, Tohoku University, \\ Sendai 980, Japan. \\ **Geachemical Research Section, Geological Survey of Japan, \\ Yatabe, Ibaraki 305, Japan.
}

\begin{abstract}
The $\mathrm{K}$-Ar and fission track ages of quartz diorite bodies related to the Chichibu pyrometasomatic deposits were determined. The $\mathrm{K}$-Ar biotite age from $\mathrm{C}$ body (Eastern intrusive body) is $6.59 \pm 0.27 \mathrm{Ma}$. The fission track dating on zircon from the same sample gives the concordant age of less than $8.1 \mathrm{Ma}$. The $\mathrm{K}-\mathrm{Ar}$ biotote and hornblende ages from $\mathrm{A}$ body (Western intrusive body) are $5.87 \pm 0.37$ and $10.5 \pm 1.5 \mathrm{Ma}$, respectively. All ages obtained here correspond to the Late Miocene.

By the previous paleomagmetical work it has been determined that the $\mathrm{C}$ body or igneous activity of $\mathrm{C}$ body among many igneous phases in the mining area is responsible for ore deposition. Therefore, we conclude that the age of $6.6 \mathrm{Ma}$ which is obtained from $\mathrm{C}$ body is the mineralization age in the mining area. It is noteworthy that the mineralization of the Chichibu mining area is Late Miocene in age, whereas most other pyrometasomatic deposits in Japan were formed in Cretaceous time.
\end{abstract}

\section{Introduction}

Quartz diorite bodies accompanying the Chichibu pyrometasomatic deposits intrude the so-called Chichibu Paleozoic formation. Much attention has been focused on the age of these intrusives involved in the mineralization of the mining area. There are many opinions about the ages of these intrusives; Early Miocene (Kaneda and Watanabe, 1961), Miocene (Ishii, 1962; Miyazawa et al., 1970), Paleogene (Okubo and Horiguchi, 1969) and Miocene-Pliocene (MMAJ, 1975). However, no radiometric age has been reported. In this paper $\mathrm{K}$-Ar ages of biotite and hornblende and a fission track age from these quartz diorite bodies are reported, and the mineralization age in the Chichibu mining area is discussed.

\section{Geology and Sample Description}

The geology in the Chichibu mining district consists of the Paleozoic formations called the Nakatsugawa group (Fujimoto et al., 1950) and the igneous rocks intruding this sedimentary formation.

The Nakatsugawa group is composed of the Ishibune, Ryogami and Ohkawamata Formations in ascending order (Fujimoto et al., 1957 : Ishii, 1962; Okubo and Horiguchi, 1969). The Ishibune Formation distributed in the center of the mapped area (Fig. 1) consists of sandstone, slate, chert and limestone. The

(Manuscript received, November 1, 1985;

accepted for publication, December 4, 1985) 


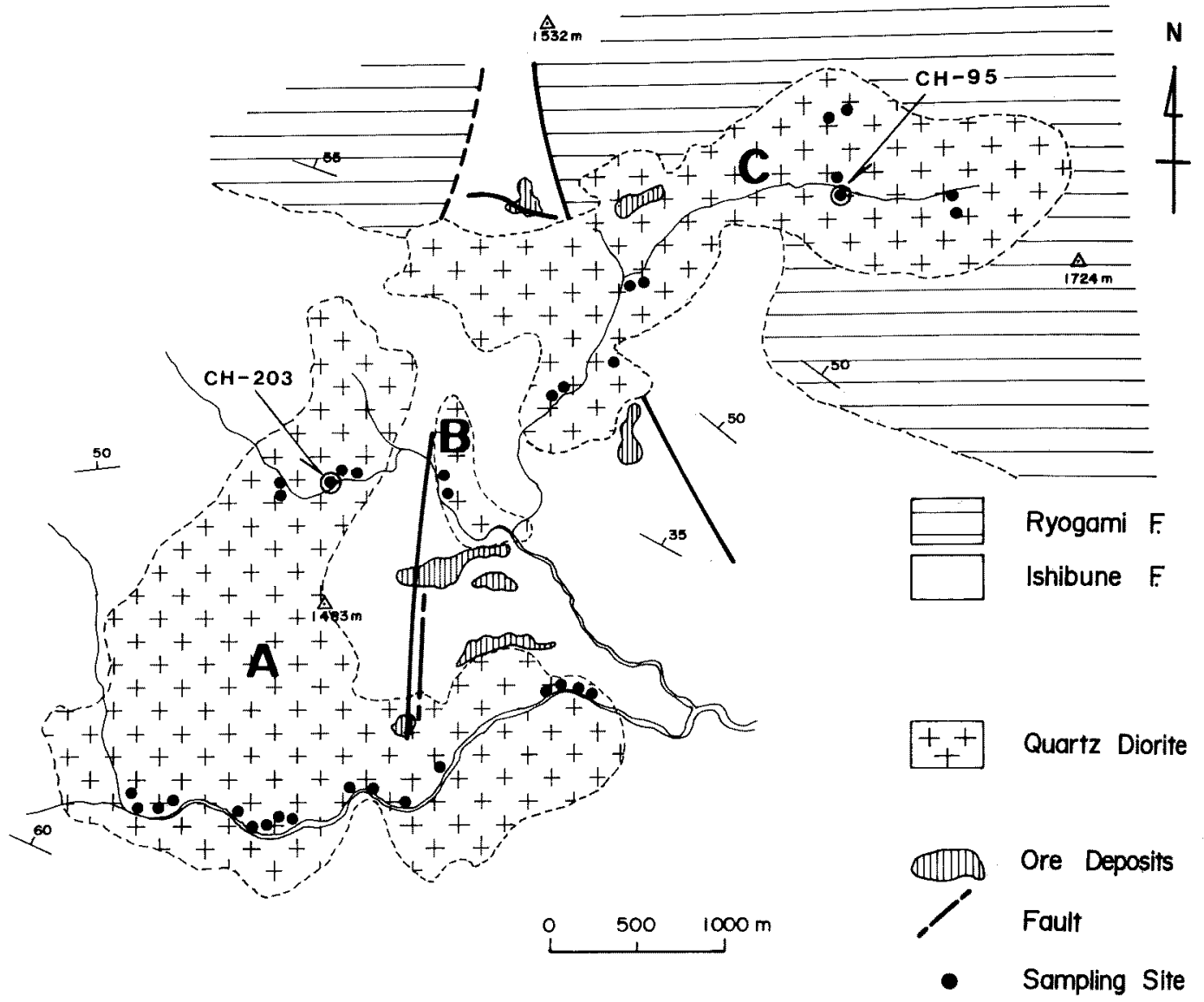

Fig. 1. Geological map of the Chichibu mining area and location of samples for radiometic age determinations.

Ryogami Formation distributed along the north side of the Ishibune Formation has siliceous phases. These formations generally strike WNW and dip NNE, and are disturbed by the intrusion of quartz diorite. It has been considered that the Nakatsugawa group belongs to the Carboniferous and Permian. However, Koike et al. (1971) and MMAJ (1975) have reported Triassic conodonts in cherts of the Ryogami Formation. It is now need to reexamine the stratigraphy and structure in the mining area. The igneous rocks intruding the Paleozoic formations are quartz diorite as stocks, and quartz porphyry and porphyrite as small dykes. Paleozoic formations within the contact zone around quartz diorite are thermally metamorphosed. The ore deposits are of pyrometasomatic type. The main ore minerals are magnetite, pyrrhotite, pyrite, sphalerite, galena and chalcopyrite, and skarn minerals are garnet, diopside, epidote, vesvianite and others. There are many ore bodies as indicated in Figure 1.

The quartz diorite bodies are called A, B and $\mathrm{C}$ bodies for convenience (Fig. 1). The wide ranged areas within quartz diorite bodies near the ore deposits and along faults are suffered from hydrothermal alteration. Those are half part of $\mathrm{A}$ and $\mathrm{C}$ bodies, and whole part of $B$ body. The freshest quart $z$ diorite samples 
for the radiometric age determination were selected among samples collected from many sites (Fig. 1).

\section{CH-95 (C body)}

At the large outcrops along the dray road to the Shigasaka tunnel, $50 \mathrm{~m}$ east of the Togeno-sawa dell.

Clinopyroxene-cummingtonite bearing orthopyroxene-biotite-hornblende quart $z$ diorite. itic.

Greyish, medium grained, slightly porphyr-

Composed of plagioclase, quartz, hornblende $(2-3 \mathrm{~mm})$, biotite $(0.5 \mathrm{~mm}$ or less), potassium feldspar, cummingtonite and clinopyroxene with accessary apatite, zircon, magnetite and ilmenite.

Fresh rock, no chlorizition on biotite.

\section{CH-203 ( $A$ body)}

At the road cut along the Hirokawa-zawa valley.

Clinopyroxene bearing orthopyroxenecummingtonite-hornblende-biotite quartz diorite.

Dark greenish grey, medium grained, equigranular.

Composed of plagioclase, quartz, biotite (0.5-1 mm), hornblende (1-2 mm), cummingtonite, potassium feldspar, orthopyroxene and clinopyroxene with accessary apatite, sphene, magnetite and ilmenite.

Relatively fresh, just a few biotite grains partly chloritized, some hornblende grains partly changed to cummingtonite.

\section{Radiometric Age Determination and Discus- sion}

The $\mathrm{K}-\mathrm{Ar}$ age determination was done on biotite and hornblende separated mechanically from the rock samples $\mathrm{CH}-203$ of $\mathrm{A}$ body and $\mathrm{CH}-95$ of $\mathrm{C}$ body. Argon was extracted and purified in the pyrex high vaccum system. The sample was fused in a molybdenum crucible at about $1,300^{\circ} \mathrm{C}$, and argon gas was purified with hot titanium sponge. Isotopic ratios of argon were measured by the Micromass 6 mass spetrometer of the Geological Survey of Japan. The patassium content was determined by atomic absorption analysis. The decay constants used in the $\mathrm{K}-\mathrm{Ar}$ age calculation are those recommended by Steiger and Jäger (1977). The error in ages is indicated at $1 \sigma$ level.

The fission track age was determined by the external detector technique using zircon crystals separated from the rock sample $\mathrm{CH}-95$ of $\mathrm{C}$ body. Sufficient zircon crystals could not be obtained from the fresh sample of $A$ body. Zircon crystals were etched by $\mathrm{KOH}$ and $\mathrm{NaOH}$. The reactor JRR-2:JRR-3 with the radioactivity of gold foil monitors was used for irradiation. The total error was estimated to be the square root of the squares of errors in spontaneous densities, induced densities and thermal neutron fluxes.

Results of the age determinations are indicated in Tables 1 and 2 . The $\mathrm{K}$-Ar biotite age from the sample $\mathrm{CH}-95$ of $\mathrm{C}$ body is $6.6 \mathrm{Ma}$. On the other hand the fission track age from the same sample is 8.1 Ma. Kaneoka(1983) has pointed out the possibility that the adopted method counting total tracks from whole mineral sections gives relatively old ages. Then, this age of $8.1 \mathrm{Ma}$ represents only the maximun age of $\mathrm{C}$ body, and the radiometric age of $\mathrm{C}$ body ought to be $6.6 \mathrm{Ma}$. The $\mathrm{K}-\mathrm{Ar}$ ages from the sample $\mathrm{CH}-203$ for biotite and hornblende: $5.87 \pm 0.37 \mathrm{Ma}$ and $10.5 \pm 1.5 \mathrm{Ma}$ respectively, are greatly discordant. Hornblende is known to be the most retentive among minerals used for $\mathrm{K}$ $\mathrm{Ar}$ dating, and often gives an age older than that of the coexisting biotite. However, such a great discordance between biotite and hornblende as shown above has not been reported yet 
Table 1. K-Ar ages of quartz diorite from the Chichibu mining area

\begin{tabular}{|c|c|c|c|c|c|c|}
\hline Sample No. & Mineral & $\begin{array}{l}\mathrm{K}_{2} 0 \\
(\%)\end{array}$ & $\begin{array}{c}40 \mathrm{Ar} \mathrm{rad} \\
\left(10^{-6} \mathrm{~m} 1 \mathrm{STP} / \mathrm{g}\right)\end{array}$ & A tm. ${ }_{(\%)}^{40} \mathrm{Ar}$ & & $\begin{array}{l}\text { Age } \\
\text { (Ma) }\end{array}$ \\
\hline $\begin{array}{l}\mathrm{CH}-95 \\
(\mathrm{C} \text { body })\end{array}$ & Biotite & 5.81 & 1.24 & 52.4 & & $6.59 \pm 0.27$ \\
\hline \multirow[t]{2}{*}{$\begin{array}{l}\mathrm{CH}-203 \\
(\mathrm{~A} \text { body })\end{array}$} & Biotite & 8.34 & $\begin{array}{l}1.58 \\
1.63\end{array}$ & $\begin{array}{l}52.8 \\
83.2\end{array}$ & & $\begin{array}{l}5.85 \pm 0.25 \\
6.06 \pm 0.72 \\
\end{array}$ \\
\hline & & & & & Av. & $5.87 \pm 0.37$ \\
\hline \multirow[t]{2}{*}{$\begin{array}{l}\mathrm{CH}-203 \\
(\mathrm{~A} \text { body) }\end{array}$} & Hornblende & $0.460,0.454$ & $\begin{array}{l}0.153 \\
0.157\end{array}$ & $\begin{array}{l}90.4 \\
89.6\end{array}$ & & $\begin{array}{l}10.3 \pm 2.2 \\
10.6 \pm 2.1\end{array}$ \\
\hline & & & & & Av. & $10.5 \pm 1.5$ \\
\hline
\end{tabular}

Calculated using following constants: ${ }^{40} \mathrm{~K} \lambda_{\beta}=4.962 \times 10^{-10} / \mathrm{y},{ }^{40} \mathrm{~K} \mathrm{~A}_{\mathrm{e}}=0.581 \times 10^{-10} / \mathrm{y}$, and ${ }^{40} \mathrm{~K} / \mathrm{K}=0.01167$ atom \% (Steiger and Jäger, 1977).

Table 2. Fission track age of quartz diorite from the Chichibu mining area

\begin{tabular}{lccccc}
\hline \hline Sample No. & Mineral & $\begin{array}{c}\mathrm{Ps}_{\mathrm{c}} \\
\left(\mathrm{t} / \mathrm{cm}^{2}\right)\end{array}$ & $\begin{array}{c}\mathrm{Pi} \\
\left(\mathrm{t} / \mathrm{cm}^{2}\right)\end{array}$ & $\begin{array}{c}\phi \\
\left(\mathrm{n} / \mathrm{cm}^{2}\right)\end{array}$ & $\begin{array}{c}\text { Age } \\
(\mathrm{Ma})\end{array}$ \\
\hline \begin{tabular}{c} 
CH-95 $(\mathrm{C}$ body $)$ \\
\hline
\end{tabular} & Zircon & 6.57 & 38.5 & $0.805 \times 10^{15}$ & $8.1 \pm 1.4$ \\
\hline
\end{tabular}

Ps; spontaneous track density, $P_{i}$; induced track density, $\phi$; thermal neutron fluence. Calculated using following constants: $\lambda_{d}\left({ }^{238} \mathrm{U}\right)=1.55125$ and ${ }^{235} \mathrm{U} /{ }^{238} \mathrm{U}=7.2527 \times 10^{-3}$ (Steiger and Jäger, 1977); $\lambda_{f}\left({ }^{238} \mathrm{U}\right)=7.03 \times 10^{-17}$ (Roberts et al., 1968).

for granitic rocks in Japan. There are some possible interpretations as the excess ${ }^{40} \mathrm{Ar}$ in hornblende, reheating by the later $\mathrm{C}$ body, and others. Clearly many more observations on igneous phases in this area and young granitic rocks in other areas are needed before a proper assessment about the discordance can be made, but it is clear that all the ages obtained in this area fall in the Late Miocene.

The related rock of the Chichibu pyrometasomatic deposits is assumed to be the quartz diorite by the geographic distribution of the acidic intrusives adjacent to the ore deposits (Kaneda and Watanabe, 1961 ; Okubo and Horiguchi, 1969 ; Miyazawa et al., 1970; MMAJ, 1975). Recently the related rock of the Chichibu pyrometasomatic deposits was examined by comparing the magnetization in ores with that of igneous rocks (Ueno et al. $1975 ; 1978$ ). The hematite and pyrrhotite ores have the reversed magnetization. The magnetization of $\mathrm{C}$ body is reversed, while that of A body is normal. Then, the related rock of the ore deposits is determined to be $\mathrm{C}$ body from the consideration of contemporaneous magnetization (Ueno et al, 1978). The temperature at which argon is retained is not so high. In addition to it, the magnetization of plutonic intrusives is acquired at the relatively low temperature. Although ore deposits are formed obviously after plutonic emplacement, the difference between the time at which the potassium-argon clock is set and also the magnetization of plutonic intrusives is acquired 
and the time at which ore minerals crystallize to be magnetized may not so large. Therefore, it is concluded that the mineralization age in the mining area is the same age as $6.6 \mathrm{Ma}$ obtained from $\mathrm{C}$ body.

Almost all pyrometasomatic deposits in Japan were formed in Cretaceous time. It is noteworthy that the Chichibu deposits being one of typical pyrometasomatic deposits in Japan are Late Miocene in age.

Acknowledgments: We wish to express our appreciation to the following personnels who provided assistance during this study. The fission track dating procedure was done by Dr. Shiro Tamanyu, Geological Survey of Japan. The technical assistance for $\mathrm{K}-\mathrm{Ar}$ dating was given by Mr. Shigeru Uchiumi, Geological Survey of Japan. Dr. Shoji Tonouchi, Ocean Research Institute, University of Tokyo; Dr. Munetomo Nedachi, Kagoshima University ; and Prof. Satoshi Kanisawa, Tohoku University gave us their helpfulness and co-operation. This study was partly supported by the Grant-in-Aid for Scientific Research from the Ministry of Education, Science and Culture.

\section{References}

Fujimoto, H., Kawada, K., Miyazawa, T., Morikawa, R., Arai. F., Takano, T., Yoshida, S., Hara, K., Tazuke, H. and Madoo, H. (1950), Geological studies of the Oku-chichibu region. Bull. Chichibu Museum Natural History, No.1, 1-28 (in Japanese).

Fujimoto, H., Miyazawa, T., Kawada, K., Asano, K. and Kaneda, M. (1957), Geology of the Okuchichibu district and the Chichibu mining area. Geol. Soc. Japan 64th Annual Meeting Excursion Guide Book, 1-31 (in Japanese).

Ishii, A. (1962), Upper Paleozoic of the Nakatsu- gawa area, Okuchichibu, Kanto-massif, Bull. Chichibu Museum Natural History, No. 11, 1-22 (in Japanese).

Kaneda, M. and Watanabe, A. (1961), On the geol. ogy and prospecting of the Akaiwa and Doshin kubo deposits, Chichibu mine. Mining Geol. 11, 481-490 (in Japanese).

Kaneoka, 1. (1983), On the radiometric ages of volcanic rocks from the northeastern part of the Honshu Island, Japan. Mining Geol. Special Issue, No. 11, 69-78 (in Japanese).

Kitamura K. (1975), Al-Fe Partitioning between garnet and epidote from the contact metasomatic copper deposits of the Chichibu mine, Japan. Econ. Geol., 70, 725-738.

Koike, T., Igo, H., Takizawa, S. and Kinoshita, T. (1971), Contribution to the geological history of the Japanese Islands by the conodont biostratigraphy, Part 2. J. Geol. Soc. Japan, 77, 165-168.

Miyazawa, T., Hashimoto, M. and Harada, K. (1970), Crystalline schists of the Nagatoro area, and geology and ore deposits of the Chichibu mine. IMA-IAGOD Joint Meeting 1970 Excursion Guidebook No. 5, 8-49.

MMAJ (Metal Mining Agency of Japan, 1975), Report on the regional geological survey, Chichibu district. Ministry International Trade and Industry, Tokyo (in Japanese).

Okubo, M. and Horiguchi, M. (1969), Geology of the Mamba district. Geol. Survey Japan, Quadrangle series, Tokyo, No.26, 66 p (in Japanese).

Roberts, J.A., Gold, R. and Armani, R.J. (1968), Spontaneous-fission decay constant of ${ }^{238} \mathrm{U}$. Phys. Rev., 174, 1482-1484.

Steiger, R.H. and Jäger, E. (1977), Subcommision on Geochronology: Convention on the use of decay constants in geo-and cosmochronology. Earth Planet. Sci. Letters, 36, 359-362.

Ueno, H., Nedachi, M. and Tonouchi, S. (1975) Related rocks of pyrometasomatic deposits: Part 1, Paleomagnetical research. Sci. Rept. Tohoku Univ., ser. 3, 13, 1-12.

Ueno, H., Tonouchi, S. and Shibata, K. (1978), Paleomagnetical evidence for the genesis of the Chichibu pyrometasomatic deposits, Japan (Abstract). Abstracts of IAGOD Fifth Sym posium helt at Snowbird, USA, p. 194. 


\section{秩父鉱山周辺の石英閃緑岩の放射年代と鉱床生成期}

$$
\text { 上野宏共・柴田賢 }
$$

进入時期について種々の意見のあった当地域の石英閃緑岩の $\mathrm{K}-\mathrm{Ar}$ 年代とフィッション・トラック年代 を測定した。東部のC岩体からは6.6 Ma K-Ar 年代と8.1 Ma 以下と解釉されるフィッション・トラック年 代を得た。西側の $\mathrm{A}$ 岩体からは $5.9 \mathrm{Ma}$ 黑雲母 $\mathrm{K}-\mathrm{Ar}$ 年代と $10.5 \mathrm{Ma}$ 普通角閃石 $\mathrm{K}-\mathrm{Ar}$ 年代を得た。測定值 の隔りについては一部には十分に説明できない点もあるが，いずれの測定年代も後期中新世に入る。鉱床 生成に真接関連寸るC岩体の $6.6 \mathrm{Ma}$ が当鉱床の生成年代之結諭できる。 